\title{
Aplikasi Biochar dengan Pupuk Kandang Terhadap Pertumbuhan dan Produksi Kacang Tanah (Arachis hypogaea L.)
}

\author{
The Application of Biochar with Cow Manure to the \\ Peanut (Arachis hypogaea L.) Development and Production
}

\author{
Fadhlina, Jamidi dan Usnawiyah \\ Jurusan Agroteknologi Fakultas Pertanian Universitas Malikussaleh \\ Muara Batu Lhokseumawe.Email: usnafp@gmail.com
}

\begin{abstract}
Abstrak
Penelitian ini bertujuan untuk mengetahui sejauh mana pengaruh pemberian biochar dan pupuk kandang sapi serta interaksi keduanya terhadap pertumbuhan dan produksi kacang tanah. Penelitian ini dilaksanakan di Desa Reuleut Barat Kecamatan Muarabatu Kabupaten Aceh Utara yang berlangsung dari bulan April sampai September 2015. Penelitian ini menggunakan Rancangan Acak Kelompok (RAK) faktorial dengan 3 ulangan, dimana ada dua faktor yang diteliti yaitu jenis biochar (B) dan pupuk kandang sapi (K), masing-masing terdiri dari B0 (tanpa biochar), B1 (biochar 5 ton/ha) dan K0 (tanpa pupuk kandang), K1 (pupuk kandang 5 ton/ha), K2 (pupuk kandang 10 ton/ha). Hasil penelitian menunjukkan bahwa penggunaan biochar (B) tidak berpengaruh nyata terhadap tinggi tanaman, diameter batang, jumlah daun, jumlah cabang, jumlah ginofor, berat polong per tanaman, berat kering 100 biji serta berat kering biji per plot. Tetapi memberikan pengaruh sangat nyata terhadap panjang akar. Selanjutnya pemberian pupuk kandang sapi $(\mathrm{K})$ berpengaruh sangat nyata terhadap tinggi tanaman pada umur 15 hari setelah tanam. Terdapat interaksi terhadap tinggi tanaman pada umur 15 hari setelah tanam dan tinggi tanaman pada umur 30 hari setelah tanam. Pemberian biochar memberikan pengaruh yang sangat nyata pada pertumbuhan tanaman kacang tanah dan pemberian pupuk kandang sapi juga memberikan pengaruh yang sangat nyata pada pertumbuhan tanaman kacang tanah. Terdapat interaksi antara pemberian biochar dan pupuk kandang sapi terhadap pertumbuhan tanaman kacang tanah.
\end{abstract}

Kata kunci: biochar, pupuk kandang sapi, kacang tanah

\begin{abstract}
The main aim of this study is to investigate the effect of the use of biochar and cow manure and their interaction with peanut production and growth. This research was conducted in Reuleut Barat Village, Muara Batu Sub-district, North Aceh Regency which conducted from April to September 2015. This research used Factorial Randomized Block Design with 3 replications. Two factors studied: biochar (B) and manure cow $(\mathrm{K})$, each consisting of B0 (without biochar), B1 (biochar 5 tons / ha) and K0 (without manure), K1 (manure 5 tons / ha), K2 (manure 10 tons / ha). The results showed that the use of biochar (B) had no significant effect on plant height, stem diameter, number of leaves, number of branches, amount of ginofor, weight of pod per plant, dry weight of 100 seeds and dry weight of seed per plot. But it gives a significant influence on the root length. Furthermore, the application of cow manure $(\mathrm{K})$ has a very significant effect on plant height at age 15 days after planting. There is interaction to plant height at 15 days after planting and plant height at 30 days after planting. The application of biochar gave an effect significantly on the growth of peanut crops and the application of cow manure also affected the growth of peanut crops. There is an interaction between the application of biochar and cow manure to the growth of peanut crops.
\end{abstract}

Keywords: biochar, cow manure, peanut

\section{Pendahuluan}

Kacang tanah (arachis hipogea L.) merupakan tanaman pangan berupa semak yang berasal dari Amerika Selatan, tepatnya berasal dari Brazilia. Penanaman pertama kali dilakukan oleh orang Indian (suku asli bangsa Amerika) (Prihatman, 2000).

Kacang tanah memiliki kandungan protein $25-30 \%$, lemak $40-50 \%$, karbohidrat 
12\% serta vitamin B1. Kacang tanah mengandung anti oksidan, yaitu senyawa tokoferol, selain itu mengandung arakhidonat, dan mineral (Kalsium, Magnesium, Phosphor, dan Sulfur), serta vitamin (riboflavin, thianin, asam nikotinik, vitamin $\mathrm{E}$, dan vitamin A). Hal ini menempatkan kacang tanah sebagai tanaman legum ke-2 di Indonesia setelah kedelai (Cibro, 2008).

Nugrahaeni dan Kasno (1992) menyatakan bahwa kacang tanah sebagian besar $66 \%$ dihasilkan di lahan kering dan sisanya 34\% dihasilkan di lahan basah. Hasil kacang tanah di lahan kering masih jauh lebih rendah, hanya 2 ton/ha ${ }^{-1}$ dibandingkan dengan hasil kacang tanah di lahan basah yang dapat mencapai 4,5 ton/ha ${ }^{-1}$ (BPPP, 1999). Produktivitas lahan dan produksi tanaman di lahan kering masih rendah karena sebagian besar lahan kering mempunyai tingkat kesuburan rendah dan sumber air terbatas hanya tergantung pada curah hujan yang distribusinya tidak dapat diatur sesuai dengan kebutuhan tanaman (Andrianto dan Indarto, 2004).

Pembuatan biochar sudah dikenal sejak 2000 tahun yang lalu di Amazon (Terra Preta). Kegiatan ini mengubah limbah pertanian menjadi pembenah tanah yang dapat mengikat karbon, meningkatkan keamanan pangan dan mengurangi pembukaan hutan. Proses tersebut menghasilkan serat yang baik dan arang yang sangat porous yang membantu tanah menahan hara dan air (IBI, 2012). Biochar merupakan bahan kaya karbon yang berasal dari biomassa seperti kayu maupun sisa hasil pengolahan tanaman yang dipanaskan dalam wadah dengan sedikit atau tanpa udara (Lehmann dan Joseps, 2009). Biochar telah diketahui dapat meningkatkan kualitas tanah dan digunakan sebagai salah satu alternatif untuk pembenah tanah (Gani, 2009). Pemberian biochar ke tanah. berpotensi meningkatkan kadar C-tanah, retens $\boldsymbol{2}$. air dan unsur hara di dalam tanah. Gani (20093. menyatakan bahwa keuntungan lain dari biochar adalah bahwa karbon pada biochar bersifat stabil dan dapat tersimpan selama ribuan tahun di dalam tanah.

Selain pemberian biochar, menambahkan pupuk organik juga bermanfaat dalam meningkatkan kesuburan tanah dan meningkatkan kualitas lahan secara berkelanjutan. Penggunaan pupuk organik akan mengembalikan bahan organik kedalam tanah yang akan berpengaruh pada kesuburan tanah sehingga terjadi peningkatan produksi tanaman. Salah satu pupuk organik yang dapat digunakan untuk memperbaiki kesuburan tanah ialah pupuk kandang (Wiroatmodjo et al,1990).

Pupuk kandang merupakan pupuk organik dari hasil fermentasi kotoran padat dan cair (urin) hewan ternak yang umumnya berupa mamalia (sapi, kambing, kuda) dan unggas (ayam, burung) (Simanungkalitet al, 2006).

Pemberian pupuk kandang selain dapat menambah tersedianya unsur hara, juga dapat mendukung pertumbuhan mikroorganisme serta mampu memperbaiki struktur tanah. Pupuk kandang memiliki sifat yang alami dan tidak merusak tanah, dan pupuk kandang menyediakan unsur makro (nitrogen, fosfor, kalium, kalsium dan belerang) serta unsur mikro (besi, seng, boron, kobalt dan molibdenium (Mayadewi, 2007).

\section{Bahan dan Metode}

Penelitian ini dilaksanakan di Reuleut Barat Kecamatan Muarabatu Kabupaten Aceh Utara dan Laboratorium Fakultas Pertanian Universitas Malikussaleh Kampus Utama Reuleut Kecamatan Muarabatu Kabupaten Aceh Utara dengan ketinggian $\pm 18 \mathrm{~m}$ dpl. Penelitian ini dilaksanakan dari bulan April sampai September 2015.

Bahan yang digunakan adalah benih kacang tanah varietas Gajah, biochar sekam, pupuk kandang sapi. Sedangkan alat yang digunakan adalah cangkul, garu, tali rafia, meteran, timbangan analitik, jangka sorong, gembor dan alat tulis menulis.

Penelitian ini menggunakan Rancangan Acak Kelompok (RAK) pola faktorial, dengan dua faktor yang diteliti, yaitu:

a. Faktor biochar (B):

$\mathrm{B} 0=$ Kontrol

B1 = 5 ton/ha $(84.37 \mathrm{gr} /$ lubang tanam $)$

b. Faktor dosis pupuk kandang sapi $(\mathrm{K})$ :

$\mathrm{K} 0=$ Kontrol

$\mathrm{K} 1=5 \mathrm{ton} / \mathrm{ha}(84.37 \mathrm{gr} /$ lubang tanam)

$\mathrm{K} 2=10$ ton/ha (168.75 gr/lubang tanam)

Dengan demikian kombinasi percobaan masingmasing tiga ulangan, sehingga secara keseluruhan terdapat 18 unit percobaan. Adapun susunan kombinasi perlakuan dapat dilihat pada Tabel 1.

Tabel 1. Susunan kombinasi perlakuan antara penggunaan biochar dan pupuk kandang sapi.

\begin{tabular}{cccc}
\multirow{2}{*}{ Biochar } & \multicolumn{3}{c}{ Pupuk Kandang Sapi } \\
\cline { 2 - 4 } & $\mathrm{K}_{0}$ & $\mathrm{~K}_{1}$ & $\mathrm{~K}_{2}$ \\
\hline $\mathrm{B}_{\mathbf{0}}$ & $\mathrm{B}_{0} \mathrm{~K}_{0}$ & $\mathrm{~B}_{0} \mathrm{~K}_{1}$ & $\mathrm{~B}_{0} \mathrm{~K}_{2}$
\end{tabular}


$\begin{array}{llll}\mathrm{B}_{1} & \mathrm{~B}_{1} \mathrm{~K}_{0} & \mathrm{~B}_{1} \mathrm{~K}_{1} & \mathrm{~B}_{1} \mathrm{~K}_{2}\end{array}$ Model matematika untuk rancangan acak kelompok (RAK) faktorial adalah sebagai berikut :

$$
Y_{i j k}=\mu+\beta_{i}+K_{j}+E_{k}+(K E)_{j k}+\varepsilon_{i j k}
$$

Keterangan :

$\boldsymbol{Y}_{i j k}=$ Nilai pengamatan dari faktor 1 taraf ke-i faktor II ke-j pada ulangan ke $\mathrm{k}$

$\boldsymbol{\mu} \quad=$ Rata-rata (nilai tengah)

$\boldsymbol{\beta}_{\boldsymbol{i}} \quad=$ Pengaruh blok ke-i

$\boldsymbol{K}_{j} \quad=$ Pengaruh biochar ke-j

$\boldsymbol{E}_{\boldsymbol{k}} \quad=$ Pengaruh pupuk kandang ke-k

$(\boldsymbol{K E})_{j k}=$ Interaksi pada faktor biochar ke-j dan faktor pupuk kandang sapi ke-k

$\varepsilon_{i j k}=$ Pengaruh acak faktor biochar ke-I dan pupuk kandang sapi ke-j pada ulangan ke-k

Data hasil pengamatan dianalisa secara statistik dengan menggunakan program SAS dan apabila berpengaruh nyata dan sangat nyata maka dilakukan uji lanjut dengan menggunakan uji Duncan.

\section{Pelaksanaan Penelitian}

Pengolahan tanah dilakukan secara manual dengan mencangkul, menggaru dan mencabut gulma-gulma yang masih tersisa, pengolahan dilakukan dengan cara mencangkul sampai kedalaman $30 \mathrm{~cm}$ lalu diratakan. Setelah lahan diolah dan dibuat bedengan dengan ukuran 150 × $180 \mathrm{~cm}$ sebanyak 18 petak dengan jarak antara petak $50 \mathrm{~cm}$ dan berfungsi sebagai drainase.

Penanaman dilakukan pada pagi hari, dengan cara ditugal. Setiap lubang tanam diisikan 1 benih dengan kedalaman $3-5 \mathrm{~cm}$ dan jarak tanam 40 x $30 \mathrm{~cm}$. Penanaman dilakukan 1 (satu) minggu setelah persiapan lahan. Pemupukan diberikan 7 hari sebelum penanaman dengan dosis 168,75 gr/lubang tanam dan 84,37 gr/lubang tanam, sedangkan pada umur 15 hari setelah tanam pemupukan kembali dilakukan dengan pemberian pupuk NPK Rusia dengan dosis $0,84 \mathrm{gr} /$ tanaman.

Pemberian biochar dilakukan 7 hari sebelum penanaman, dengan dosis 84,37 gr/lubang tanam. Biochar idealnya ditempatkan dekat permukaan tanah di daerah perakaran, dimana siklus unsur hara dan penyerapan oleh tanaman terjadi. Sistem tertentu bisa mendapat manfaat dari aplikasi biochar di lapisan bawah daerah perakaran, jika biochar diaplikasikan semata-mata untuk tujuan mengikat karbon, penempatan yang lebih dalam di tanah akan lebih disukai.

Penyiraman dilakukan pada pagi dan sore hari dengan menggunakan gembor dan bertujuan untuk menjaga kelembaban tanah. Apabila turun hujan, maka penyiraman tidak dilakukan karena kebutuhan air telah terpenuhi melalui air hujan.

Penyiangan dilakukan untuk membersihkan gulma rumput atau gulma lain yang tumbuh di areal penalitian. Penyiangan dilakukan setelah tanaman berumur satu minggu setelah tanam. Pengendalian hama dan penyakit pada tanaman kacang tanah dilakukan pada 25 hari setelah tanam dengan menggunakan insektisida furadon $3 \mathrm{G}$. Pemanenan dilakukan setelah tanaman kacang tanah telah masak fisiologis yang ditandai dengan batang mulai mengeras, daun menguning dan sebagian mulai berguguran, polong sudah berisi penuh dan keras dan warna polong coklat kehitam-hitaman.

\section{Hasil dan Pembahasan}

Tabel 2. Rekapitulasi hasil analisis ragam pemberian biochar (B) dan pupuk kandang (K) serta interaksi keduanya

\begin{tabular}{|c|c|c|c|c|}
\hline Tolak Ukur & $\begin{array}{c}\text { Biochar } \\
\text { B } \\
\end{array}$ & $\begin{array}{c}\text { Pupuk kandang } \\
\text { K }\end{array}$ & $\begin{array}{c}\text { Interaksi } \\
(\mathrm{B} \times \mathrm{K}) \\
\end{array}$ & $\mathrm{KK}(\%)$ \\
\hline \multicolumn{5}{|l|}{ Tinggi Tanaman } \\
\hline $15 \mathrm{HST}$ & tn & $* *$ & $* *$ & 11,35 \\
\hline $30 \mathrm{HST}$ & tn & tn & $*$ & 14,46 \\
\hline $45 \mathrm{HST}$ & tn & $\operatorname{tn}$ & $\operatorname{tn}$ & 12,66 \\
\hline $60 \mathrm{HST}$ & tn & tn & tn & 12,22 \\
\hline Diameter Batang & tn & tn & $\operatorname{tn}$ & 8,60 \\
\hline \multicolumn{5}{|l|}{ Jumlah Daun } \\
\hline $15 \mathrm{HST}$ & tn & tn & $\operatorname{tn}$ & 20,08 \\
\hline
\end{tabular}




\begin{tabular}{|c|c|c|c|c|}
\hline $30 \mathrm{HST}$ & tn & tn & tn & 17,22 \\
\hline $45 \mathrm{HST}$ & tn & tn & tn & 8,44 \\
\hline $60 \mathrm{HST}$ & tn & tn & tn & 8,76 \\
\hline \multicolumn{5}{|l|}{ Jumlah Cabang } \\
\hline $15 \mathrm{HST}$ & tn & tn & tn & 28,01 \\
\hline $30 \mathrm{HST}$ & tn & tn & tn & 20,99 \\
\hline $45 \mathrm{HST}$ & tn & tn & tn & 9,21 \\
\hline $60 \mathrm{HST}$ & tn & tn & tn & 63,69 \\
\hline Jumlah Ginofor & tn & tn & tn & 16,67 \\
\hline Jumlah Polong Per Rumpun & tn & tn & tn & 16,55 \\
\hline Panjang Akar & $* *$ & tn & tn & 10,75 \\
\hline Berat Kering 100 biji & tn & tn & tn & 9,43 \\
\hline berat kering biji per plot & tn & tn & tn & 34,31 \\
\hline
\end{tabular}

Rekapitulasi hasil analisis sidik ragam pada Tabel 2 menunjukkan bahwa terjadi interaksi antara dua faktor yang teliti yaitu memberikan pengaruh sangat nyata pada peubah tinggi tanaman pada umur 15 hari setelah tanam dan berpengaruh nyata terhadap tinggi tanaman pada umur 30 hari setelah tanam.

Faktor pemberian biochar tidak berpengaruh nyata terhadap tinggi tanaman pada umur tanaman 15 sampai 60 hari setelah tanam, diameter batang, jumlah daun pada umur 15 sampai 60 hari setelah tanam, jumlah cabang pada umur 15 sampai 60 hari setelah tanam, jumlah ginofor, berat polong per tanaman, berat kering 100 biji serta berat kering biji per plot, tetapi memberikan pengaruh sangat nyata terhadap panjang akar.

Faktor pemberian pupuk kandang sapi berpengaruh sangat nyata pada peubah tinggi tanaman pada umur 15 hari setelah tanam tetapi tidak memberikan pengaruh terhadap peubah lainnya.

\section{Tinggi Tanaman}

Hasil análisis sidik ragam menunjukkan bahwa perlakuan pemberian biochar tidak berpengaruh nyata terhadap tinggi tanaman pada umur 15, 30, 45 dan 60 hari setelah tanam (Lampiran 4, 6, 8 dan 10).

Sedangkan perlakuan pemberian pupuk kandang sapi memberikan pengaruh yang sangat nyata terhadap tinggi tanaman kacang tanah pada umur 15 hari setelah tanam, tidak berpengaruh nyata pada umur 30,45 dan 60 hari setelah tanam dan terdapat interaksi antara perlakuan pemberian biochar dengan perlakuan pemberian pupuk kandang sapi terhadap tinggi tanaman pada umur 15 dan 30 hari setelah tanam (Lampiran 4, 6, 8 dan 10).

Rata-rata tinggi tanaman kacang tanah pada umur 15, 30, 45 dan 60 hari setelah tanam akibat perlakuan pemberian biochar dapat dilihat pada Tabel 3 dan terdapat interaksi akibat perlakuan pemberian biochar dengan pemberian pupuk kandang sapi dapat dilihat pada Tabel 3.

Tabel 3. Rata-rata tinggi tanaman $(\mathrm{cm})$ kacang tanah pada umur 15 dan 30 hari setelah tanam akibat perlakuan pemberian biochar dan pemberian pupuk kandang sapi.

\begin{tabular}{cccc}
\hline \multirow{2}{*}{ Perlakuan } & \multicolumn{3}{c}{ Pupuk Kandang Sapi } \\
\cline { 2 - 4 } & K0 & Tinggi tanaman umur 15 HST \\
\hline Biochar & 1,80 & 1,76 & K2 \\
\hline B0 & 1,61 & 1,67 & 2,69 \\
B1 & \multicolumn{3}{c}{ Pupuk Kandang sapi } \\
\hline \multirow{2}{*}{ Perlakuan } & Tinggi tanaman umur 30 HST \\
\cline { 2 - 4 } &
\end{tabular}




\begin{tabular}{cccc}
\hline Biochar & K0 & K1 & K2 \\
\hline B0 & 6,54 & 5,71 & 5,06 \\
B1 & 5,02 & 5,57 & 7,16 \\
\hline
\end{tabular}

Keterangan: Angka-angka yang dikuti oleh huruf yang sama pada kolom yang sama tidak berbeda nyata pada uji Duncan taraf $5 \%$

Tabel 3 menunjukkan bahwa tinggi tanaman kacang pada umur 15 dan 30 hari setelah tanam akibat perlakuan pemberian biochar dan pupuk kandang sapi tertinggi terdapat pada perlakuan B1K2 yaitu $2,49 \mathrm{~cm}$ dan $7,16 \mathrm{~cm}$ dan tinggi tanaman yang terendah pada umur 15 hari setelah tanam terdapat pada perlakuan B1K0 dengan tinggi yaitu $1,61 \mathrm{~cm}$. Tinggi tanaman yang terendah pada umur 30 hari setelah tanam terdapat pada perlakuan B1K0 dengan tinggi tanaman yaitu $5,02 \mathrm{~cm}$. Hal ini sesuai pernyataan (Suyamto, 1993) bahwa hasil tanaman kacang tanah sangat ditentukan oleh ketersediaan unsur hara, baik unsur hara makro maupun unsur hara mikro.

Pemberian biochar dan pupuk kandang sapi memberikan pengaruh yang baik terhadap pertumbuhan tinggi tanaman, dikarenakan biochar mampu memberikan unsur hara yang cukup untuk pertumbuhan kacang tanah. Hal ini sesuai pendapat (Glauser et al, 2002) bahwa biochar berfungsi sebagai pembenah tanah, meningkatkan pertumbuhan tanaman dengan memasok sejumlah nutrisi yang berguna serta meningkatkan sifat fisik, kimia dan biologi tanah.

Hasil penelitian lainnya, menunjukkan bahwa biochar dapat menambah kelembaban dan kesuburan tanah pertanian. Di samping itu, dalam konteks pengurangan emisi $\mathrm{CO} 2$, biochar persisten dalam tanah bahkan dilaporkan sampai ribuan tahun (Gani, 2010).

Selain pemberian biochar yang dapat mendukung pertumbuhan tinggi tanaman, pemberian pupuk kandang sapi juga dapat meningkatkan pertumbuhan tinggi tanaman kacang tanah, hal ini dikarenakan pupuk kandang sapi memiliki kandungan nitrogen yang umumnya dirubah menjadi bentuk nitrat tersedia. Nitrat adalah mudah larut dan bergerak ke daerah perakaran tanaman. Bentuk ini sama dengan bentuk yang bisa diambil oleh tanaman dari sumber pupuk anorganik dari pabrik (Nursyamsi et al, 1995).

Tabel 4. Rata-rata tinggi tanaman $(\mathrm{cm})$ kacang tanah pada umur 15 sampai 60 hari setelah tanam akibat perlakuan pemberian biochar dan pemberian pupuk kandang sapi.

\begin{tabular}{ccccc}
\hline \multirow{2}{*}{ Perlakuan } & \multicolumn{5}{c}{ Tinggi Tanaman } \\
\cline { 2 - 5 } & 15 HST & 30 HST & 45 HST & 60 HST \\
\hline Biochar & & & 13,16 & 17,69 \\
\hline B0 & 1,75 & 5,77 & 13,52 & 18,26 \\
B1 & 1,93 & 5,92 & 13,70 & 17,38 \\
\hline PupukKandang & 1,71 & 5,78 & 13,16 & 18,13 \\
K0 & 1,72 & 5,64 & 13,16 & 18,42 \\
K1 & 2,09 & 6,11 & &
\end{tabular}

Keterangan : Angka-angka yang dikuti oleh huruf yang sama pada kolom yang sama tidak berbeda nyata pada uji Duncan taraf $5 \%$

Tabel 4 menunjukkan bahwa tinggi tanaman kacang tanah yang tertinggi pada umur 45 dan 60 hari setelah tanam akibat perlakuan pemberian biochar (B1) yaitu $13,54 \mathrm{~cm}$ dan $18,26 \mathrm{~cm}$ dan tinggi tanaman kacang tanah yang terendah terdapat pada perlakuan tanpa pemberian biochar (B0) menghasilkan tinggi tanaman kacang tanah yaitu $13,16 \mathrm{~cm}$ dam 17,79 $\mathrm{cm}$.

Pada umur 45 dan 60 HST tinggi tanaman kacang tanah yang tertinggi terdapat pada perlakuan tanpa pupuk kandang sapi (K0) menghasilkan tinggi tanaman kacang tanah yaitu $13,70 \mathrm{~cm}$, sedangkan pada umur 60 tinggi tanaman yang tertinggi terdapat pada perlakuan 
pemberian pupuk kandang sapi (K2) dengan tinggi tanaman yaitu $18,42 \mathrm{~cm}$. Tetapi tanaman kacang tanah yang terendah pada pemberian pupuk kandang sapi pada umur 45 HST yaitu pada perlakuan K1 dan K2 (13,16 cm dan 13,16 $\mathrm{cm}$ ) dan pertumbuhan 60 HST pada perlakuan $(17,38 \mathrm{~cm})$.

Pemberian biochar dan pupuk kandang sapi memberikan pengaruh yang baik terhadap pertumbuhan tinggi tanaman. Pemberian biochar dan pupuk kandang sapi dapat meningkatkan pertumbuhan tinggi tanaman dikarenakan biochar dan pupuk kandang sapi merupakan bahan organik yang dapat meningkatkan ketersediaan kation utama dan fosfor, total $\mathrm{N}$ dan kapasitas tukar kation tanah (KTK) yang pada akhirya dapat meningkatkan hasil (Gani, 2010), dan menyediakan unsur hara yang cukup untuk meningkatkan pertumbuhan tinggi tanaman kacang tanah.

\section{Diameter Batang}

Hasil analisis ragam menunjukkan bahwa perlakuan pemberian biochar dan pupuk kandang sapi tidak memberikan pengaruh yang nyata terhadap diameter batang tanaman kacang tanah serta tidak terdapat interaksi antara perlakuan pemberian biochar dan pupuk kandang sapi terhadap diameter batang kacang tanah pada umur 60 hari setelah tanam (Lampiran 12). Ratarata diameter batang kacang tanah pada umur 60 hari setelah tanam akibat perlakuan pemberian biochar dan pupuk kandang sapi dapat dilihat pada Tabel 5.

Tabel 5. Rata-rata diameter batang $(\mathrm{mm})$ tanaman kacang tanah akibat perlakuan pemberian biochar dan pupuk kandang sapi pada umur 60 hari setelah tanam

\begin{tabular}{cc}
\hline \multirow{2}{*}{ Perlakuan } & Diameter Batang \\
\cline { 2 - 2 } & 60 HST \\
\hline Biochar & \\
\hline B0 & 0,43 \\
B1 & 0,44 \\
\hline Pupuk Kandang Sapi & 0,43 \\
K1 & 0,44 \\
K2 & 0,44 \\
\hline
\end{tabular}

Keterangan: Angka-angka yang dikuti oleh huruf yang sama pada kolom yang sama tidak berbeda nyata pada uji Duncan taraf $5 \%$

Tabel 5 menunjukkan bahwa diameter batang tanaman kacang tanah akibat perlakuan pemberian biochar pada umur 60 hari setelah tanam yang terbaik terdapat pada perlakuan B1 dengan diameter batang yaitu $0,44 \mathrm{~mm}$. Diameter batang tanaman kacang tanah yang terendah terdapat pada perlakuan B0 dengan diameter batang $0,43 \mathrm{~mm}$.

Tabel 5 menunjukkan bahwa diameter batang tanaman kacang tanah akibat perlakuan pemberian pupuk kandang sapi yang terbaik terdapat pada perlakuan pemberian pupuk kandang sapi (K1 dan K2) dengan diameter batang yaitu $0,44 \mathrm{~mm}$ dan diameter batang yang terendah terdapat pada perlakuan K0 dengan diameter yaitu 0,43 mm.Pemberian pupuk kandang sapi dapat meningkatkan diameter batang tanaman kacang tanah, hal ini diduga karena pupuk kandang sapi mempunyai kemampuan mengubah berbagai faktor dalam tanah, sehingga menjadi faktor-faktor yang menjamin kesuburan tanah dan mengandung sejumlah unsur hara makro dan mikro yang dibutuhkan oleh tanaman kacang tanah. Kandungan pupuk Kandang dalam tiap ton adalah $85 \% \quad \mathrm{H}_{2} 0,2-2,6 \% \mathrm{~N}, 0,26-0,45 \% \mathrm{P}$, 0,13-1,37\% K (Warjito, 2002).

\section{Jumlah Daun Kacang Tanah}

Hasil analisis ragam menunjukkan bahwa perlakuan pemberian biochar dan pupuk kandang sapi tidak berpengaruh nyata terhadap jumlah daun kacang tanah. Tidak terdapat interaksi antara perlakuan pemberian biochar dan perlakuan pemberian pupuk kandang sapi (Lampiran 14, 16, 18 dan 20) .

Rata-rata jumlah daun kacang tanah pada umur 15, 30, 45 dan 60 hari setelah tanam akibat perlakuan pemberian biochar dan perlakuan pemberian pupuk kandang sapi dapat dilihat pada Tabel 6 
Tabel 6. Rata-rata jumlah daun (helai) tanaman kacang tanah akibat perlakuan pemberian biochar dan perlakuan pemberian pupuk kandang sapi pada umur 15, 30, 45 dan 60 hari setelah tanam

\begin{tabular}{ccccc}
\multirow{2}{*}{ Perlakuan } & \multicolumn{4}{c}{ Jumlah Daun (Helai) } \\
\cline { 2 - 5 } & 15 HST & 30 HST & 45 HST & 60 HST \\
\hline Biochar & 3,54 & 16,75 & 34,64 & 47,58 \\
B0 & 3,75 & 19,00 & 36,33 & 47,94 \\
B1 & 3,50 & 17,42 & 34,54 & 46,38 \\
\hline Pupuk Kandang & 3,72 & 18,71 & 35,54 & 48,17 \\
K0 & 3,71 & 17,50 & 36,17 & 48,75 \\
\hline
\end{tabular}

Keterangan: Angka-angka yang dikuti oleh huruf yang sama pada kolom yang sama tidak berbeda nyata pada uji Duncan taraf $5 \%$

$\begin{array}{ccc}\text { Hasil penelitian menunjukkan bahwa } \\ \text { perlakuan } & \text { pemberian biochar dapat }\end{array}$ meningkatkan jumlah daun tanaman kacang tanah dari umur 15 sampai umur 60 hari setelah tanam. Perlakuan pemberian biochar B1 menghasilkan jumlah daun sebanyak 3,75, 19,00, 36,33 dan 47,94 helai. Jumlah daun yang terendah dari umur 15 sampai 60 hari setelah tanam terdapat pada perlakuan B0 dengan jumlah daun yaitu 3,54, 16,75, 34,64 dan 47,58 helai. Pada perlakuan pemberian pupuk kandang sapi, jumlah daun yang terbanyak pada umur 15 sampai 45 hari setelah tanam terdapat pada perlakuan pemberian pupuk kandang sapi (K1) dengan jumlah daun yang dihasilkan adalah 3,72 , 18,71 dan 35,54 helai sedangkan pada umur 60 HST jumlah daun yang terbanyak terdapat pada perlakuan pemberian pupuk kandang sapi (K2) dengan jumlah daun yang dihasilkan adalah sebanyak 48,75 helai. Jumlah daun yang terendah dari umur 15 sampai 60 hari setelah tanam akibat perlakuan pemberian pupuk kandang sapi terdapat pada perlakuan kontrol K0 dengan jumlah daun yaitu $3,50,17,42,34,54$, dan 46,38 helai.

Peningkatan jumlah daun disebabkan oleh peranan dari unsur $\mathrm{N}$ yang terdapat dalam pupuk kandang sapi, Burhanuddin dan Nurmansyah (2010) menyatakan nitrogen yang berasal dari pupuk kandang sapi umumnya dirubah menjadi bentuk nitrat tersedia sehingga

Tabel 7. Rata-rata jumlah cabang (tangkai) tanaman kacang tanah akibat pemberian biochar dan pupuk kandang sapi terhadap jumlah cabang tanaman kacang tanah pada umur 30, 45 dan 60 hari setelah tanam.

\begin{tabular}{ccccc}
\hline \multirow{2}{*}{ Perlakuan } & \multicolumn{3}{c}{ Jumlah Cabang } \\
\cline { 2 - 5 } & 15 HST & 30 HST & 45 HST & 60 HST \\
\hline B0 & 3,64 & 5,36 & 8,22 & 24,28 \\
B1 & 3,83 & 5,61 & 8,58 & 28,69
\end{tabular}

mudah larut dan bergerak pada daerah perakaran tanaman.

Dalam pembentukan daun diperlukan adanya unsur hara yangn cukup agar jumlah daun yang dihasilkan banyak. Dengan adanya pemberian pupuk kandang sapi dapat meningkatkan jumlah daun. Selain unsur $\mathrm{N}$ dan $\mathrm{K}$ pupuk kandang sapi juga mengandung unsur hara Mg. Adanya kandungan unsur hara $\mathrm{Mg}$ dapat lebih meningkatkan jumlah daun. Hasil penelitian Supriyadi (2001), menyatakan bahwa tanaman yang diberi pupuk daun $\mathrm{Mg}$ menghasilkan jumlah daun lebih banyak dibandingkan tanpa pupuk Mg. Ini dikarenakan unsur hara $\mathrm{Mg}$ merupakan penyusunan pigmen klorofil pada tanaman yang berperan mengambil dan mengubah energi cahaya menjadi bentuk yang dapat digunakan dalam proses fotosintesis.

\section{Jumlah Cabang}

Hasil analisis ragam menunjukkan bahwa perlakuan pemberian biochar dan pupuk kandang sapi tidak berpengaruh nyata terhadap jumlah cabang tanaman kacang tanah. Tidak terdapat interaksi antara perlakuan pemberian biochar dan perlakuan pemberian pupuk kandang sapi. Rata-rata jumlah cabang tanaman kacang tanah pada umur 30, 45 dan 60 HST akibat perlakuan pemberian biochar dan perlakuan pemberian pupuk kandang sapi dapat dilihat pada Tabel 7. 


\begin{tabular}{lllll}
\hline K0 & 3,63 & 5,38 & 8,29 & 21,83 \\
K1 & 3,54 & 5,50 & 8,38 & 26,29 \\
K2 & 4,04 & 5,58 & 8,54 & 31,33 \\
\hline
\end{tabular}

Keterangan: Angka-angka yang dikuti oleh huruf yang sama pada kolom yang sama tidak berbeda nyata pada uji Duncan taraf $5 \%$

Tabel 7 menjelaskan bahwa jumlah cabang yang terbanyak pada umur $15,30,45$ dan 60 hari setelah tanam pada perlakuan pemberian biochar terdapat pada perlakuan B1 dengan masingmasing jumlah cabang yang diperoleh adalah $3,83,5,61,8,58$ dan 28,69. sedangkan jumlah cabang yang terendah terdapat pada perlakuan B0. Pada perlakuan pemberian pupuk kandang sapi jumlah cabang yang terbanyak terdapat pada perlakuan K2 dengan masing-masing jumlah cabang yang diperoleh yaitu 4,04, 5,58, 8,54 dan 31,33 cabang. Sedangkan jumlah cabang yang terendah terdapat pada perlakuan K0.

\section{Jumlah Ginofor, Jumlah Polong Per Tanaman, Panjang Akar, Berat Kering 100 biji dan Berat Kering biji per plot}

Hasil analisis ragam menunjukkan bahwa perlakuan pemberian biochar tidak berpengaruh nyata terhadap jumlah ginofor, jumlah polong per rumpun, berat kering 100 biji dan berat kering biji per plot tetapi berpengaruh sangat nyata terhadap panjang akar. Hal ini diperkuat dengan pendapat Suwardjono (2004) yang menyatakan bahwa struktur tanah yang baik menjadikan perakaran berkembang dengan baik sehingga semakin luas bidang serapan terhadap unsur hara. Perlakuan pemberian pupuk kandang sapi tidak berpengaruh nyata terhadap semua peubah yang diamati. Tidak terdapat interaksi antara perlakuan pemberian biochar dan perlakuan pemberian pupuk kandang sapi terhadap semua peubah yang diamati (Lampiran 30, 32, 34, 36 dan 38) .

Rata-rata jumlah ginofor, jumlah polong per tanaman, berat kering 100 biji, panjang akar dan berat kering biji per plot akibat perlakuan pemberian biochar dan perlakuan pemberian pupuk kandang sapi dapat dilihat pada Tabel. 8

Tabel 8. Rata-rata jumlah ginofor, jumlah polong per tanaman, berat kering 100 biji, panjang akar dan berat kering biji per plot kacang tanah akibat perlakuan pemberian biochar dan pupuk kandang sapi.

\begin{tabular}{|c|c|c|c|c|c|}
\hline \multirow[b]{2}{*}{ Perlakuan } & \multicolumn{3}{|c|}{ Pengamatan } & & \multirow[b]{2}{*}{ Berat per plot } \\
\hline & $\begin{array}{l}\text { Jumlah } \\
\text { ginofor }\end{array}$ & $\begin{array}{l}\text { jumlah } \\
\text { polong }\end{array}$ & $\begin{array}{c}\text { Panjang } \\
\text { akar }\end{array}$ & Berat 100 & \\
\hline \multicolumn{6}{|l|}{ Biochar } \\
\hline B0 & 121,69 & 62,25 & $9,82 \mathrm{~b}$ & 55,22 & 282,22 \\
\hline B1 & 109,05 & 67,67 & $12,81 \mathrm{a}$ & 59,61 & 314,11 \\
\hline \multicolumn{6}{|c|}{ Pupuk Kandang } \\
\hline K0 & 113,29 & 57,96 & 11,08 & 57,01 & 250,83 \\
\hline K1 & 110,50 & 61,08 & 11,62 & 58,58 & 352,50 \\
\hline $\mathrm{K} 2$ & 122,33 & 75,83 & 11,25 & 56,66 & 291,17 \\
\hline
\end{tabular}

Keterangan: Angka-angka yang dikuti oleh huruf yang sama pada kolom yang sama tidak berbeda nyata pada uji Duncan taraf $5 \%$

Hasil penelitian menunjukkan bahwa jumlah polong yang terbanyak terdapat pada perlakuan B1 dengan jumlah polong yaitu 67,67 polong dan jumlah ginofor yang terbanyak terdapat pada perlakuan B0 dengan jumlah 121,69 ginofor. Untuk panjang akar, berat 100 biji dan berat biji per plot yang terbaik terdapat pada perlakuan B1 dengan panjang akar yaitu $12,81 \mathrm{~cm}$, berat 100 biji yaitu $59,61 \mathrm{gr}$ dan berat biji per plot yaitu 314,11 gr. Jumlah ginofor yang terendah terdapat pada perlakuan B1 dengan jumlah polong 109,05 polong dan jumlah polong yang terendah terdapat pada perlakuan K0 yaitu 57,96 polong. Untuk panjang akar, berat 100 biji dan berat biji per plot yang terendah terdapat pada perlakuan B0 yaitu dengan panjang akar $9,82 \mathrm{~cm}$, berat kering 100 biji yaitu 55,22 gr dan berat kering biji per plot yaitu 282,22 gram. 
Pada perlakuan pemberian pupuk kandang sapi jumlah ginofor yang terbanyak terdapat pada perlakuan $\mathrm{K} 2$ dengan jumlah ginofor yaitu 122,33 ginofor dan jumlah ginofor yang terendah terdapat pada perlakuan K1 dengan jumlah ginofor yang dihasilkan yaitu 110,50 ginofor. Jumlah polong yang terbanyak terdapat pada perlakuan K2 dengan jumlah polong yang didapatkan yaitu 122,33 polong dan jumlah polong yang terendah terdapat pada perlakuan K1 dengan jumlah polong yaitu 110,50 polong. Panjang akar yang terpanjang terdapat pada perlakuan K1 dengan panjang akar

\section{Simpulan}

1. Perlakuan pemberian biochar tidak memberikan pengaruh terhadap pengamatan tinggi tanaman, diameter batang, jumlah daun, jumlah cabang, jumlah ginofor, jumlah polong per rumpun, berat kering 100 biji dan berat kering 100 biji perplot. Namun memberikan pengaruh yang sangat baik terhadap panjang akar dengan dosis perlakuan biochar adalah 84,37 gr/tanaman.

2. Perlakuan pemberian pupuk kandang sapi dengan dosis 168,75 gr/tanaman memberikan pengaruh sangat baik terhadap pengamatan tinggi tanaman pada umur 15 hari setelah tanam, tetapitidak memberikan pengaruh terhadap pengamatan lainnya.

3. Terdapat interaksi terhadap tinggi tanaman pada umur 15 hari setelah tanam dan pada umur 30 hari setelah tanam antara perlakuan pemberian biochar dan perlakuan pemberian pupuk kandang sapi.

\section{Daftar Pustaka}

Adimihardja, A., I, Juarsah., U. Kurnia. 2000. Pengaruh Penggunaan Berbagai Jenis dan Takaran Pupuk Kandang Terhadap Produktivitas Tanah Ultisols Terdegradasi. Pusat Penelitian Tanah dan Agroklimat. Bogor.

Adrianto, T.T., Indarto, N. 2004. Budidaya dan Analisis Usaha Tani Buncis, Kacang Tanah, Kacang Tunggak. Absolut.Yogyakarta.

Ashley, J. M. 1996. Kacang Tanah dalam Goldsworthy, P. G., Fisher, N. M., editor. Fisiologi Tanaman Budidaya Tropik. University Press. Gajah Mada.Yogyakarta.

Askari, Wahyu. 2010. Tanaman Kacang Tanah. yaitu 11,62 $\mathrm{cm}$ dan panjang akar yang terendah terdapat pada perlakuan K0 dengan panjang akar yaitu $11,08 \mathrm{~cm}$.

Pada pengamatan berat 100 biji berat yang terbaik terdapat pada perlakuan pemberian pupuk kandang sapi K1 dengan berat yaitu 58,58 gr dan yang terendah terdapat pada perlakuan $\mathrm{K} 2$ dengan berat yaitu 56,66 gr, pada pengamatan berat biji per plot yang terbaik terdapat pada perlakuan $\mathrm{K} 1$ dengan berat biji yaitu $352,50 \mathrm{gr}$ dan berat biji per plot yang terendah terdapat pada perlakuan K0 dengan berat biji yaitu 250.83 gr.

(https://wahyuaskari.wordpress.com/ak ademik/tanaman-kacang-tanah/).

BPPP. 1999. Laporan Tahunan Balitkabi. Malang: Badan Penelitian dan Pengembangan Pertanian. Balai Penelitian Tanaman Kacang Kacangan dan Umbi - Umbian.

Burhanuddin., Nurmansyah. 2010. Pengaruh Pemberian Pupuk Kandang dan Kapur Terhadap Pertumbuhan dan Produksi Nilam Pada Tanah Podsolik Merah Kuning. Bul. Littro.

Cahyono, B. 2007. Budidaya Kacang Tanah. Teknik Budidaya Pengelolaan Analisis Usaha Tani. Aneka Ilmu. Semarang.

Cibro, M.A. 2008. Respon Beberapa Varietas Kacang Tanah (Arachis hypogaea L.) Terhadap Pemakaian Mikoriza Pada Berbagai Cara Pengolahan Tanah. Universitas Sumatera Utara. Medan.

Gani, A. 2009. Biochar Penyelamat Lingkungan. Warta Penelitian dan Pengembangan Pertanian.Vol. 13, No. 6.

Gani, A. 2010. Multiguna Arang - Hayati Biochar. Balai Besar Penelitian Tanaman Padi. Sinar Tani.

Glaser, B., J. Lehmann and W. Zech. 2002. Ameliorating Physical and Chemical Properties of Highly Weathered Soils in The Tropics with Charcoal -A review. Biology and Fertility of Soils.

http://sumut.bps.go.id. 2012. Luas Panen, Produktivitas dan Produksi Kacang Tanah Menurut Kabupaten/Kota. Diakses tanggal 12 Februari 2012.

IBI. 2012. What is Biochar? International Biochar Initiative.www.biocharinternational.org.

Ismawati, E.M. 2003. Pupuk Organik. Penebar Swadaya. Jakarta. 
Lehmann, J., 2007. Bioenergy in the black.Frontiers in Ecology and the Environment Vol. 5, Hal: 381-387.

Lehmann, J., Joseph, S. 2009. Biochar for Enyironmental Manajement Sciense and Technology. Earthscan in the UK and USA.

Liang, B., Lehmann, J., Kinyangi, D., Grossman, J., O’Neill, B., Skjemstad, J.O., Thies, J., Luizao, F.J., Peterson, J., \& Neves, E.G. 2008. Black carbon increases cation exchange capacity in soils. Soil Sci. Soc. Am. J., 70, 1719-173.

Masulili, A., Utomo, W.H. \& Syekhfani, Ms. 2010. Rice Husk Biochar for Rice Based Cropping System in Acid Soil 1. The Characteristics of Rice Husk Biochar and Its Influence on the Properties of Acid Sulfate Soils and Rice Growth in West Kalimantan, Indonesia.Journal of Agricultural Science.Canada

Mayadewi, Ari. 2007. Pengaruh Jenis Pupuk Kandang dan Jarak Tanam Terhadap Pertumbuhan Gulma Hasil Jagung Manis.Agritrop.

Nursyamsi, D., sopandi, D., Erfandi, S., I P.G. Widjaja-adhi.1995. Penggunaan Bahan Organik Untuk Meningkatkan Produktivitas tanah Podsolik (typic kandiudults).Pusat Penelitian Tanah dan Agroklimat. Bogor.

Nugrahaeni, N., Kasno, A. 1992. Plasma Nutfah Kacang Tanah Toleran Terhadap Cekaman Fisik.Prosiding Simposium Penelitian Tanaman Pangan III. Malang.

Prihatman, K. 2000. Kacang Tanah (Arachis hypogaea L.). Kantor Deputi Menegristek Bidang Pendayagunaan dan Pemasyarakatan Ilmu Pengetahuan dan Teknologi. Jakarta.

Purnomo, J., I G.P, Wigena., D. Santoso. 2000. Pengelolaan Pupuk dan Bahan Organik Untuk Meningkatkan Produksi Dystropepts di Jambi.Pusat Penelitian Tanah dan Agroklimat. Bogor.

Simanungkalit, R.D.M., Didi A.S., Rasti, S., Diah, S., Wiwik, H. 2006. Pupuk Organik dan Pupuk Hayati (Biofertilizer).Balai Besar Penelitian dan Pengembangan Sumberdaya Lahan Pertanian. Bogor.

Suhaeni, N. 2007. Petunjuk Praktis Menanam Kacang Tanah. Jember. Bandung.
Sumarno. 2003. Teknik Budidaya Kacang Tanah. Sinar Baru. Bandung.

Sutedjo., Mul, M. 2002. Pupuk dan Cara Pemupukan. Rineka Cipta. Jakarta.

Suwardjono. 2004. Pengaruh Beberapa Jenis Pupuk Kandang Terhadap Pertumbuhan dan Produksi Kacang Tanah.http//www.ut.ac.id/jmst/jurna l/suwardjono/pengaruh.htm.

Suyamto, H. 1993. Hara Meneral dan Pengelolaan Air pada Tanaman Kacang Tanah. dalam Kasno, A., Winarno, A., Sunardi, editor. Kacang Tanah. Malang: Monografi Balitan Malang No 12. hal 108 - 137.

Syahriani Nor. 1995. Pengaruh Ketebalan Saringan Arang Sekam Terhadap Penurunan Kadar Warna Limbah Cair Industri Penyamakan Kulit Pt.Budi Makmur Jaya Murni di Yogyakarta. Yogyakarta..

Warjito.1994. Pengaruh Pupuk Kandang Terhadap Produksi Kubis Pada Tanah Andosol di KP Lembang. Balai Penelitian Sayuran. Lembang.

Wiroatmodjo, J., I. Hidayat U., A. Pieter L. 1990.Pengaruh Pupuk Kandang Terhadap Pertumbuhan dan Hasil Jahe (Zingiber officinale rose). Jenis Badak Serta Periode Kritis Jahe Terhadap Kompetisi Gulma.

Yunizar, N. 2007. Teknologi Pembuatan Pupuk Kandang dan Limbah Jerami Padi Dinas Pertanian Kabupaten Aceh Utara bekerja sama dengan Balai Pengkajian Teknologi Pertanian (BPTP) Aceh. 